\title{
О. О. Вороніна
}

\section{ВПРОВАДЖЕННЯ БЕВЕРІДЖСЬКОЇ МОДЕЛІ ФІНАНСУВАННЯ ОХОРОНИ ЗДОРОВ'Я: ПЕРСПЕКТИВИ ТА ЗАГРОЗИ ДЛЯ УКРАЇНИ}

У роботі визначено особливості організаиії та фінансування охорони здоров'я за Беверіджською моделлю на прикладі Великобританії. Проаналізовано національну стратегію реформування системи охорони здоров'я в Україні, виявлено ключові принципи иієї реформи. Обтрунтовано тенденції подальшого реформування та виокремлено основні проблеми $і$ ймовірні загрози. Визначено, щзо налагодження та забезпечення ефективного функціонування механізмів фінансування галузі охорони здоров'я є найголовнішою передумовою ії успішного реформування.

Ключові слова: система охорони здоров'я, модель охорони здоров'я, модель Бевериджа, джерела фінансування.

Постановка проблеми. Питання щодо системи фінансування охорони здоров'я завжди залишалися дискусійними. Досвід різних країн доводить, що недоліки існують у будь-якій моделі фінансування; із зміною суспільства, наслідками глобалізації, розвитком науки, появою нових засобів лікування та ін. змінюються проблеми охорони здоров'я, умови та фактори впливу на ії подальший розвиток. Завданням уряду країн $є$ адаптувати систему охорони здоров'я до сучасних змін, своєчасно провести необхідні заходи з регулювання, щоб уникнути загроз та ризиків для здоров'я населення. Україна нарешті визначилася з вектором свого розвитку щодо напрямів реформування національної системи охорони здоров'я, взявши за основу британську модель Бевериджа. Однак серед науковців та експертів з цього питання існують різні думки відносно обгрунтованості такого рішення.

Проблемам організації та фінансування систем медичного обслуговування населення присвячені праці багатьох вітчизняних вчених, серед яких: М. Білинська, Д. Карамишев, В. Москаленко, а також праці Я. Радиша, С. Стеценка та ін. Основні типи систем охорони здоров'я вивчали зарубіжні дослідники У. Беверидж, Ю. Лісіцин, М. Губіна, Я. Погорєлов, В. Філатов, М. Філд, М. Фотакі, С. Шишкін, О. Щепін та інші.

Однак, незважаючи на значну увагу вчених до проблем державного управління охороною здоров'я, питання визначення національної моделі та ії впровадження залишаються актуальними.

Метою статті $є$ зробити огляд системи організації та фінансування охорони здоров'я Великобританії як класичного представника Беверіджської моделі, а також проаналізувати, які елементи цієї моделі можуть отримати подальший розвиток у вітчизняних реаліях, а на які моменти слід звернути увагу.

Виклад основного матеріалу. Системи охорони здоров'я країн Західної Свропи традиційно поділяють на дві групи: створені за «беверіджською» та «бісмарківською» моделями. Першу систему (бюджетну) запропонував В. Беверидж у 1942 р. у Великій Британії. Бісмарківська модель (страхова) була заснована О. Бісмарком у 1881 р. в Німеччині. Кожна 3 цих моделей перевірена часом, випробувана різними країнами, має свої переваги та недоліки.

В цілому, розглядаючи національні моделі охорони здоров’я, важливо розуміти, який принцип фінансування покладено в основу, тому що саме цей фактор є одним із ключових при побудові всієї системи організації охорони здоров'я. Сьогодні можна виділити п'ять джерел фінансування медичної галузі:

1) із загального бюджету держави;

2) система соціального страхування, тобто певний податок, який має цільове призначення «на систему охорони здоров'я»;

3) власні платежі населення (формальні та неформальні);

4) добровільне медичне страхування;

5) інші джерела фінансування (наприклад, кошти міжнародних донорських організацій) [1].

Останні три джерела використовуються як додаткові, їх частка може бути різною залежно від організаційної структури системи охорони здоров'я, політики, що проводиться державою, рівня економічного розвитку країни і т.д. Основними ж джерелами практично в усьому світі $є$ або кошти бюджету, або спеціальні загальнообов’язкові медичні страхові фонди. 
3 01.01.18 року в Україні розпочався процес реформування національної системи охорони здоров’я, в основу якого покладена «британська» модель. Медична реформа не передбачає перехід на нові джерела фінансування, але змінюється підхід до принципів фінансування галузі: «гроші будуть йти за пацієнтом», а медичні послуги будуть надаватися в рамках окреслених програмою державних гарантій. Для реалізації цих перетворень створений новий орган виконавчої влади - Національна служба здоров'я (за аналогією з британською NHS - National Health Service - національною службою охорони здоров'я). Саме тому з'являється об'єктивний інтерес щодо вивчення досвіду Великої Британії в питаннях організаціїі та фінансування медицини.

У Великобританії організована майже виключна система бюджетного фінансування охорони здоров'я, що зумовлює ії державний характер та високий ступінь централізації управління. Такий принцип фінансування обумовлює надходження основної частини коштів із державного бюджету за рахунок загальних податкових надходжень і розподіляється зверху донизу по управлінській вертикалі. В структурі управління основна частина медичних установ належить державі, а регулювання їх діяльності здійснюється центральними і місцевими органами влади.

Всесвітня організація здоров'я характеризує національну службу охорони здоров'я Великобританії як високоефективну, тому що при високих соціально-демографічних показниках (середня тривалість життя - близько 80 років) вона має відносно невисокий (для розвинених країн) рівень витрат на охорону здоров'я - близько 6,2\% валового національного продукту. На думку багатьох експертів, саме централізоване фінансування дає змогу стримувати зростання вартості лікування [2].

Незважаючи на те, що система Національної служби охорони здоров'я (НСО3) Великобританії була піддана реформам, базові принципи фінансування та організації, закладені в іiі основу, залишилися незмінними, а саме:

- безкоштовний характер надання медичної допомоги, включаючи безкоштовне забезпечення медикаментами дітей віком до 16 років, літніх людей, яким є 60 років і більше, студентів, вагітних i пацієнтів, які страждають на деякі хронічні захворювання;

- рівний доступ до медичної допомоги для всіх верств населення; пацієнтів;

- інвестування ресурсів тільки в ті галузі охорони здоров'я, в яких є найбільша потреба у

• спрямування інвестицій у ті галузі, де вищий показник вартість - ефективність.

Головна перевага британської системи охорони здоров'я - це безкоштовна медична допомога (за винятком невеликого набору медичних послуг). Держава, за рахунок бюджетних коштів, оплачує більшу частину всіх медичних послуг, що надаються населенню. Бюджет самої галузі формується за рахунок загальних податкових надходжень до бюджету, а це приблизно 90 \% від усіх акумульованих ресурсів, 7,5\% надходить за рахунок коштів роботодавців, що сплачуються до загального фонду соціального страхування. Тут слід зазначити, що ця цифра може значно змінюватися, тому що залежить від пріоритетів, що склалися на потреби пенсійного забезпечення, страхування по безробіттю, охорони здоров'я тощо.

Приблизно 4 \% коштів НСО3 формуються з додаткових платежів населення, головним чином за виписку і оплату фіксованої вартості ліків в аптечній мережі. Тобто не має значення, скільки коштують ліки, пацієнт заплатить лише визначену законодавством чітку суму. Ця сума переглядається кожного року, але на сьогодні вона не перебільшує 10 фунтів стерлінгів.

За рамками фінансових зобов'язань НСО3 населення може одержати медичні послуги в державних і приватних установах охорони здоров'я, оплачуючи їх безпосередньо або через систему приватного медичного страхування. Загальне співвідношення між суспільним i приватним фінансуванням медичної допомоги становить відповідно 85 і $15 \%$ [3].

Таким чином, держава $\epsilon$ головним покупцем i постачальником медичної допомоги, забезпечуючи задоволення більшої частини суспільної потреби в послугах охорони здоров'я. Ринку тут відведена другорядна роль, як правило, під контролем держави.

Система добровільного медичного страхування використовується для доповнення державної системи охорони здоров'я. Об'єктом страхування є тільки ті ризики, які покриваються державною службою охорони здоров'я. Також до послуг страхових компаній вдаються тоді, коли виникає бажання уникнути головного недоліку медичного обслуговування Великобританії - це наявність черг. Іноді пацієнтам доводиться чекати кілька днів, щоб потрапити на первинний прийом до лікаря загальної практики, і кілька місяців у разі необхідності отримання вузькоспеціалізованої допомоги. 
Всі види медико-соціальної допомоги надаються населенню за принципом п'яти рівнів (рисунок 1). Перший рівень - це надання само- і взаємодопомоги, передбачає надання послуг, що базуються на широкому використанні консультаційних гарячих телефонних ліній. На цьому рівні виявляється i соціальна допомога, яка надається не медичними, а різними громадськими організаціями. Головна мета цього етапу - зменшити кількість прямих звернень до медичних установ та лікарів.

На другому рівні надається первинна медико-соціальна допомога (ПМСД). У Великобританії приблизно $90 \%$ усіх медичних послуг надаються на рівні ПМСД лікарями загальної практики, які працюють за договором 3 національними органами охорони здоров'я. Така практика дозволяє запобігати необгрунтованій госпіталізації, яка потребує значно більших ресурсів.

Незалежні лікарі загальної практики об'єднуються в групи первинної медичної допомоги i виступають у ролі фондоотримувачів. Їх фінансування відбувається за чисельністю прикріпленого до них населення згідно з встановленим нормативом, який диференціюється відповідно до віку, статі, регіону. Лікарі загальної практики виступають покупцями медичної допомоги для прикріпленого до них населення, вступають у договірні відносини зі стаціонарами і фахівцями амбулаторної ланки, розраховуючись 3 ними за надані послуги.

Сестринська допомога, яка входить до третього рівня надання медичних послуг, включає систему догляду і допомоги вдома дітям, інвалідам, хворим на деякі хронічні захворювання (бронхіальна астма, цукровий діабет тощо). При необхідності пацієнтів відвідує вдома лікар загальної практики. Такий вид допомоги надається тільки в разі реальної необхідності, яку треба довести відповідними медичними документами.

Четвертий рівень - екстрена допомога і діагностичні послуги. Цей вид допомоги надається в двох видах лікарень: дільничні та районні лікарні для надання екстреної та діагностичної допомоги пацієнтам.

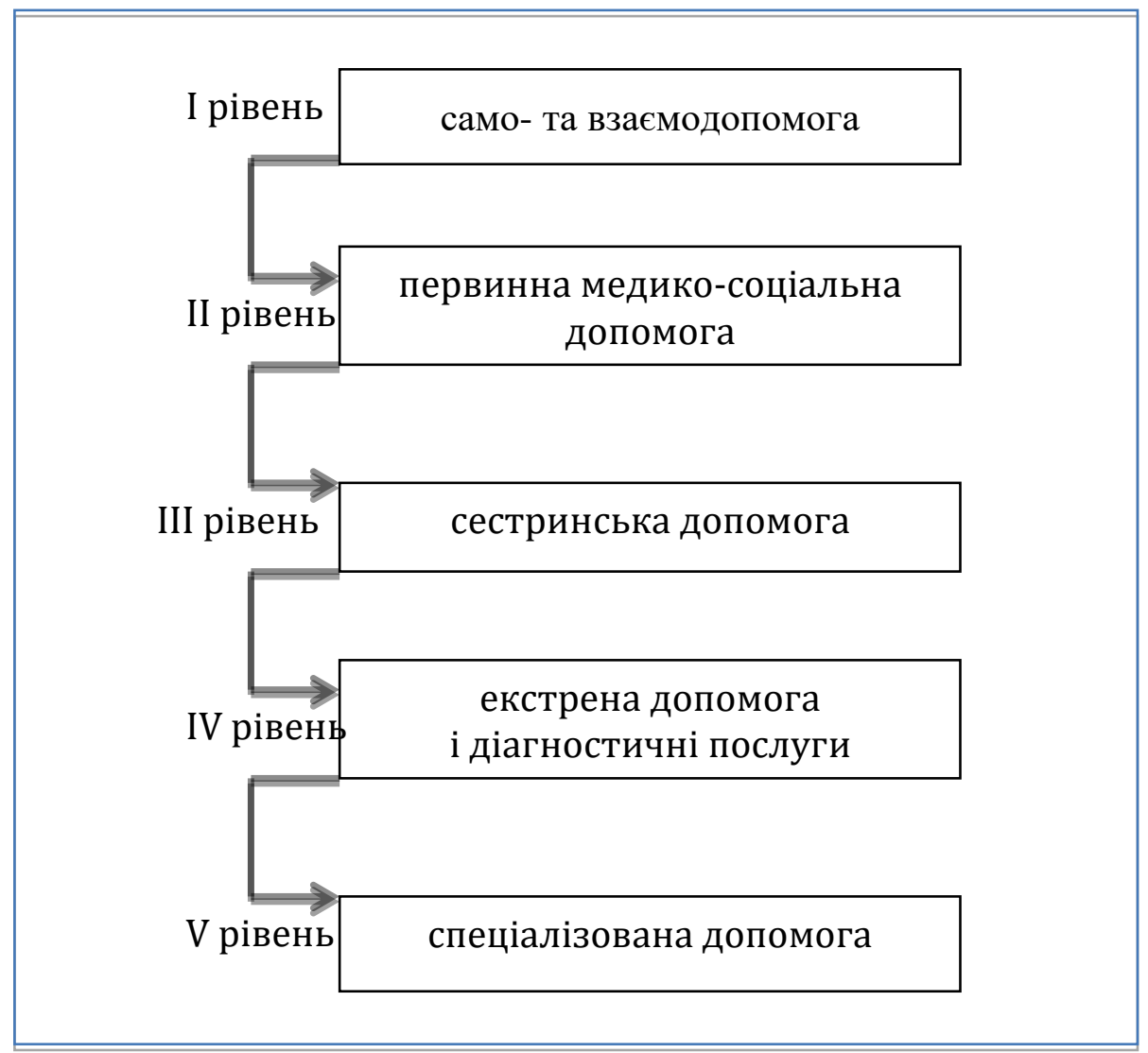

Рисунок 1 - Схема організації медико-соціальної допомоги населенню

Розроблено авторами на основі [4] 
П’ятий рівень - спеціалізована допомога (нейрохірургія, шунтування серця, пересадка органів). Цей вид допомоги надається в декількох Національних медичних центрах країни [5].

Організація роботи лікарів побудована згідно 3 концепцією «внутрішнього ринку», тобто конкурентні (ринкові) відносини між отримувачами медичних послуг та надавачами формуються всередині системи медичного обслуговування. Загальна сума коштів на фінансування НСО3 встановлюється на основі прийнятих законодавчих рішень щодо нормативів фінансування, тому ні покупці, ні виробники медичних послуг не можуть претендувати на додатковий обсяг державних коштів [3].

Проаналізувавши основні організаційні та фінансові аспекти Беверіджської системи охорони здоров'я, можна виділити ії основні риси:

1. Населенню надається безкоштовна медична допомога.

2. Доступ до безкоштовних медичних послуг має все населення.

3. Фінансування здійснюється з державного бюджету.

4. Централізована система регулювання системою охорони здоров’я.

5. Широкі професійні повноваження лікарів загальної практики.

6. Лікарі загальної практики є фондодержателями.

7. Ринку медичних послуг відведена другорядна роль.

Розробники української реформи в системі охорони здоров'я офіційно взяли за основу Беверіджську модель, тому розглянемо прояви цих характеристик в українських реаліях як імовірні перспективи і загрози.

Закон «Про державні фінансові гарантії медичного обслуговування населення» був прийнятий парламентом 19 жовтня 2017 року. Згідно з цим законом з 01 січня 2018 року в Україні почала запроваджуватися практика встановлення гарантій з медичного обслуговування, або так звана «програма державних гарантій» медичного обслуговування населення. До складу цієї програми входить перелік і обсяг медичних послуг та ліків, які оплачуються з державного бюджету на основі єдиних національних тарифів. Новим органом центральної виконавчої влади є Національна служба здоров’я України (НСЗУ), яка реалізує державну політику у сфері державних фінансових гарантій медичного обслуговування населення, а також виконує функції замовника медичних послуг та лікарських засобів за програмою медичних гарантій. Діяльність НСЗУ спрямовується і координується Кабінетом Міністрів України через міністра охорони здоров'я [6].

Гарантії держави у наданні медичного обслуговування визначають охоплення медичними послугами. Охоплення має три основні виміри:

- які послуги включено до гарантованого пакету - обсяг фінансування;

- хто може отримати доступ до них - ширина охоплення

- яка частка їх вартості сплачується за рахунок державних коштів - глибина охоплення.

Обсяг і глибина фінансування будуть визначатися, виходячи з економічної ефективності та економічної доцільності, а також на основі побудованих пріоритетів, які повинні грунтуватися, виходячи 3 таких критеріїв, як результативність, потреба в медичній допомозі, економічна ефективність послуг, захист домогосподарств від катастрофічних витрат на високовартісні послуги, рівноправність доступу та вибір населення [7].

Таким чином, згідно з новими нововведеннями конституційне право на безкоштовне медичне обслуговування населення залишається незмінним, зберігається принцип соціальної справедливості і солідарного розподілу відповідальності (коли незалежно від фінансовго стану кожний член суспільства може мати рівний доступ до медичного обслуговування). Однак на практиці цей принцип може реалізовуватися не повною мірою, і певна частка послуг (які не ввійшли до програми державних гарантій) залишається за межами фінансування держави, а отже, і витрати на всі інші послуги будуть перекладатися на гаманець пацієнтів.

Залишається принцип централізованого керування галуззю системою управління, що дозволяє стримувати зростання вартості лікування. Це, безсумнівно, - позитивна сторона централізованого бюджетного фінансування. Проте джерела фінансування охорони здоров'я замикаються на центральний державний бюджет, отже, розмір залежить від інших статей державних витрат і, більш того, конкурує з ними. Тому принцип залишкового фінансування фактично залишається в дещо завуальованому вигляді. Якщо сума коштів на охорону здоров'я виділяється невелика і $\epsilon$ недостатньою для задоволення усіх потреб, гарантований державою перелік безкоштовних послуг буде звужуватись, а можливості акумуляції додаткових коштів досить обмежені. Варто зазначити, що 
вже нині держава не фінансує ліки, а також у Програмі Національної стратегії реформування системи охорони здоров'я в Україні 2015-2020 зазначено, що розвиток стоматології буде відбуватися без прямого контролю з боку держави, втручання держави буде обмежуватися ліцензуванням діяльності через залучення професійних асоціацій та спілок [8].

Великобританія як одна 3 найзаможніших країн світу виділяє значні кошти на фінансування охорони здоров'я, i іï громадяни отримують досить широке коло безкоштовних медичних послуг, але останнім часом проблеми фінансування з'являються і в неї. Факти такі, що NHS хронічно і жорстко недофінансовується, лікарням не вистачає ні ліжок, ні персоналу, щоб успішно вирішувати проблеми зі здоров'ям старіючого населення, тому принцип доступності та всеохопленості також виконується не повною мірою.

Слід зазначити, що при державній системі охорони здоров'я брак асигнувань на ці цілі проявляється набагато гостріше, ніж у країнах зі страховою або приватною медициною. Так, у кінці 90-х років, наприклад, в Англії, де переважає державна система охорони здоров'я, кількість комп'ютерних томографів на 1 млн. жителів становила 2,7, у той час як у Німеччині - 7,7; хірургічних операцій на коронарних артеріях англійські лікарі робили в 10 разів менше, ніж у США (в розрахунку на душу населення) [9].

Крім того, згідно з новою системою оплати праці медичні працівники первинної ланки сімейні лікарі - отримують кошти за кількістю закріплених за ними пацієнтів. Керівники закладів первинної медичної допомоги (ПМД) повинні укласти договори про надання послуг із Національною службою здоров'я України (НСЗУ). Після цього вони мають право отримувати кошти з державного бюджету згідно 3 встановленими нормативами. Такі бюджетні обмеження змушують медиків економити, обмежують масштаби використання дорогої і не завжди потрібної техніки, знижують ймовірність зловживань, значно рідше трапляються випадки нав'язування пацієнтам непотрібних процедур, маніпуляцій, ліків з метою отримання додаткового доходу. Лікарі загальної практики $\epsilon$ основною ланкою охорони здоров'я, вони вирішуватимуть, чи треба пацієнту консультація або лікування у вузького спеціаліста, таким чином, і вся відповідальність за стан здоров'я хворого зосереджується на них. 3 другого боку, як свідчить досвід Великобританії, у пацієнта з'являється ризик того, що він буде змушений значно довше чекати хірургічної операції або прийому фахівця. Така двочергова система $є$ прикладом нерівноправності, суперечить законодавству будь-якої цивілізованої країни і викликає багато протестів з боку громадськості у Великій Британії.

Висновки. Реалізувати на практиці всі зазначені критерії, закладені в програму реформування, і дотримуватися принципів Беверіджської (бюджетної) моделі фінансування, буде, на наш погляд, досить складно з огляду на те, що це потребує значних економічних ресурсів, якими на сьогодні держава не володіє у достатній кількості. Тому виникають сумніви стосовно успіху цієї реформи. Викликає занепокоєння ефективність цієї моделі з точки зору можливості застосування іiї в умовах перехідної економіки, адже для такої економіки характерні наступні риси: дефіцит державного бюджету, спад виробництва, високий рівень безробіття, низький рівень доходів населення, високі темпи інфляції. В таких умовах, з одного боку, погіршується якість життя та зростає потреба в медичних послугах, а функціонування лікувально-профілактичних установ потребує, передусім, безперебійного фінансування. А з другого боку, треба ще більше коштів, щоб згладити негативні соціальні наслідки.

Для забезпечення мінімально необхідного обсягу фінансування лікувально-профілактичних установ потрібно консолідувати всі можливі джерела залучення коштів. Світовий досвід показує, що в умовах дефіциту державного бюджету і низьких доходів населення тільки соціально-страхова модель 3 багатоканальною системою фінансування (з прибутку страхових організацій, відрахувань від зарплати, державного бюджету) здатна вирішити це завдання. Тому треба докласти неабияких зусиль, щоб реформа принесла позитивні результати, і держава змогла дійсно виправдати всі взяті на себе зобов'язання.

\section{Список використаної літератури}

1. Гузій О.В. Фінансування за новим принципом та медичне обслуговування населення: роз'яснення фахівців. URL: https://www.umj.com.ua/article/130089/finansuvannya-za-novim-printsipom-ta-medichneobslugovuvannya-naselennya-roz-yasnennya-fahivtsiv

2. Trends for England and Wales (national, regional and local areas) in the average number of years people will live beyond their current age measured by "period life expectancy". URL: https://www.ons.gov.uk/peoplepopulation 
andcommunity/birthsdeathsandmarriages/lifeexpectancies/bulletins/lifeexpectancyatbirthandatage65bylocalareasin englandandwales/2015-11-04\#national-life-expectancy-at-birth

3. Медичне страхування в Україні, Великобританії, Канаді, Німеччині, Бельгії. URL: http://kradmin.gov.ua/start.php?q=Posgromad/Ua/MedStrah/2.html

4. Шекера О. Г. Системний аналіз фінансування охорони здоров'я та медичного страхування в cвiтi. URL: http://healthy-society.com.ua/index.php?option=com_content\&view=article\&id=161:2011-06-10-15-27$11 \&$ catid=36:2011-04-19-08-30-45\&Itemid=58

5. Игнатьева Р. К., Черная Н. Л., Антипова Н. П. Система медико-социальной помощи населению в Великобритании и России: плюсы и минусы. URL: https://www.eurolab.ua/encyclopedia/565/46485/

6. Сайт Національної служби здоров’я України. URL: https://nszu.gov.ua/pro-nszu

7. Програма медичних гарантій: впровадження в Україні. URL: http://moz.gov.ua/uploads/0/3798programa_medicnih_garantij_vprovadzenna_v_ukraini.pdf

8. Національна стратегія реформування системи охорони здоров’я в Україні 2015-2020 pp. URL: http://uoz.cn.ua/strategiya.pdf

9. Матвієнко M. Французька i британська моделі охорони здоров'я (огляд). URL: http://msvitu.com/archive/2014/may/article-9.php

\section{References}

1. Guziy, O. V. FInansuvannya za novym pryntsypom ta medychne obslugovuvannya naselennya: roz'yasnennya fahivtsiv [Financing by new principle and health service of population: explanations of specialists]. URL: https://www.umj.com.ua/article/130089/finansuvannya-za-novim-printsipom-ta-medichne-obslugovuvannyanaselennya-roz-yasnennya-fahivtsiv

2. Trends for England and Wales (national, regional and local areas) in the average number of years people will live beyond their current age measured by "period life expectancy". URL: https://www.ons.gov.uk/peoplepopulationandcommunity/birthsdeathsandmarriages/lifeexpectancies/bulletins/lifeex pectancyatbirthandatage65bylocalareasinenglandandwales/2015-11-04\#national-life-expectancy-at-birth

3. Medychne strahuvannya v Ukrayini, Velykobrytaniyi, Kanadi, Nimechchyni, Belgiyi [Medical insurance in Ukraine, Great Britain, Canada, Germany, Belgium]. URL: http://kradmin.gov.ua/start.php?q=Posgromad/Ua/MedStrah/2.html

4. Shekera, O. G. Systemnyy analiz finansuvannya ohorony zdorov'ya ta medychnoho strahuvannya v sviti [System analysis of the health service and medical insurance financing in the world]. URL: http://healthysociety.com.ua/index.php?option=com_content\&view=article\&id=161:2011-06-10-15-27-11\&catid=36:2011-0419-08-30-45\&Itemid=58

5. Ignatyeva, R. K., Chernaya, N. L., Antipova, N. P. Sistema mediko-sotsialnoy pomoschi naseleniyu v Velikobritanii i Rossii: plyusyi i minusyi [The system of medical and social help to the population in Great Britain and Russia: advantages and disadvantages]. URL: https://www.eurolab.ua/encyclopedia/565/46485/

6. Sayt Natsionalnoyi sluzhby zdorov'ya Ukrayiny [Site of National health service of Ukraine]. URL: https://nszu.gov.ua/pro-nszu

7. Programa medychnyh garantiy: vprovadzhennya v Ukrayini [The program of medical guaranties: implementation in Ukraine]. URL: http://moz.gov.ua/uploads/0/3798-programa_medicnih_garantij_vprovadzenna_v_ukraini.pdf

8. Natsionalna stratehiya reformuvannya systemy ohorony zdorov'ya v Ukrayini $2015-2020 \mathrm{rr}$. [National strategy of reforming health service system in Ukraine 2015-2000]. URL: http://uoz.cn.ua/strategiya.pdf

9. Matviyenko, M. Frantsuzka i brytanska modeli ohorony zdorov'ya (oglyad) [French and British models of health service (a survey)]. URL: http://msvitu.com/archive/2014/may/article-9.php

\section{O. O. Voronina}

\section{IMPLEMENTATION OF THE BEVERAGE MODEL OF HEALTHCARE FINANCING: PROSPECTS AND THREATS FOR UKRAINE}

The work determines the peculiarities of the organization and financing of the Beverage healthcare model using the example of Great Britain. The national strategy for reforming the healthcare system in Ukraine is analyzed, and the key principles of this reform are identified. The trends for further reforming are substantiated and the main problems and possible threats are highlighted. It has been determined that the establishment and ensuring of the effective functioning of the mechanisms of the healthcare industry financing is the main prerequisite for its successful reformation. 
The World Health Organization characterizes the UK national health service as highly effective one. The Beverage healthcare model determines its national character and a high degree of centralization of management. The principle of centralized financing determines the acquisition of the main part of funds from the state budget at the expense of general tax revenues.

After analyzing the main organizational and financial aspects of the Beverage health system, we can single out its main features: free medical care is provided to the population; all population has the access to free medical services; funding comes from the state budget; wide professional opportunities of general practitioners; general practitioners are fund holders; medical services market plays a secondary role.

The developers of Ukrainian reform in the healthcare system officially have taken the Beverage model as a basis. We have studied the manifestations of these characteristics in Ukrainian reality as probable perspectives and threats.

It is concluded that it would be quite difficult to implement in practice all the criteria laid down in the reform program and comply with the principles of the Beverage (budget) financing model in Ukrainian reality. Our state does not possess sufficient resources.

To ensure the minimum required amount of funding, it is necessary to make a lot of efforts so that the reform will bring positive results and the state can really justify all the obligations undertaken.

Keywords: healthcare system, healthcare model, Beverage model, sources of financing.

Стаття надійшла до редакції 21.12.2018

DOI 10.24025/2306-4420.0.52.2019.160415

Вороніна Олена Олегівна, к.е.н., старший викладач кафедри економічної теорії і міжнародної економіки, Харківський національний університет міського господарства ім. О.М.Бекетова ORCID ID 0000-0003-4720-6447

e-mail: alena.mtkv@gmail.com

Alyona Voronina, Senior Lecturer of department of Economic Theory and International Economy, O.M. Beketov National University of Urban Economy in Kharkiv 